\title{
Dependence between the width of strip overlap and the strength of joints of one-layer bitumen sheets
}

\author{
Tomáš Petř́íček ${ }^{1, *}$, and Petr Kacálek ${ }^{1}$ \\ ${ }^{1}$ Brno University of Technology, Faculty of Civil Engineering, Institute of Building Structures, \\ Veveř́ 95, 60200 Brno, Czech Republic
}

\begin{abstract}
This paper focuses on the examination of mutual dependence of overlap width of bituminous sheets and the strength characteristics of their mechanically fastened joints. Bituminous sheets with two different widths of overlap and different degree of modification were selected as samples for experimental measurements. They are supposed to be used as single-layer mechanically fastened waterproofing membranes. The aforementioned dependence has not been explicitly documented yet. The aim of this paper is to confirm or to refute a hypothesis that a relationship exists between a different width of overlap of bituminous sheets and the strength of their joints. The formulation of the results was based on the statistical evaluation of laboratory measurement data.
\end{abstract}

\section{Introduction}

The use of one-layer mechanically fastened systems is mostly based on meeting the basic requirements and technological regulations specified by manufacturer.

High quality bitumen sheets with the total width of min. $5.0 \mathrm{~mm}$ are used for one-layer systems from bitumen sheets. Bitumen coating layer must be of sufficient quality to allow good welding properties and long-term flexibility. The sheets are most commonly reinforced with a combination of PES fleece strengthened with glass fibres laid in one or both directions. The sheet overlaps are usually set to $\min .120 \mathrm{~mm}$, although there are also sheets for which manufacturer specifies the overlap to just $100 \mathrm{~mm}$.

The critical joint spot is the presence of fastening element as a spot where force effects caused by wind sucking are captured. Full scale fusion of sufficient width of the joint is a basic requirement to provide waterproofing system ability and to transfer force effects caused by wind sucking.

\section{Overlaps of bitumen sheets}

The existing standards in force related to waterproofing membranes fail to specify the size of joints. Joints are only specified in ČSN EN 13707+A2. Flexible sheets for waterproofing

\footnotetext{
* Corresponding author: petricek.t@ffce.vutbr.cz
} 
- Reinforced bitumen sheets for roof waterproofing - Definitions and characteristics [2], however, minimum joint length is missing.

Therefore, the minimum overlap width is fully in competence of bitumen sheet manufacturers. The overlap width particularly depends on the application method of the bitumen sheet (roof cladding, substructure, one-layer or multi-layer system), on the presence of a fastening element in the joint, on surface treatment of bitumen sheet, and on joint type - whether longitudinal or transversal overlap is concerned. Regarding longitudinal overlap of one-layer mechanically fastened bitumen sheets, the minimum width is usually set by manufacturers to $120 \mathrm{~mm}$, exceptionally $100 \mathrm{~mm}$. The width in transversal direction (front joint) ranges between $100 \mathrm{~mm}$ and $150 \mathrm{~mm}$.

\section{Experimental measurement}

A pressure chamber was used in which the composition of a roof membrane from a real joint segment of mechanically fastened waterproofing could be subjected to defined stresses. This wind load test is defined in the Approval Guideline for systems of mechanically fastened waterproofing membranes ETAG 006 [6].

Experimental measurements tests were carried out on a standard tensile testing machine. The samples were roof membrane segments, not just the waterproofing membrane. Two metal fastening strips in the arms of the upper grip of the machine held the waterproofing membrane in place. These arms transferred the force of the applied stress to the tested material. A pad, to which the waterproofing membrane was fastened by thermal insulation, was clamped into the lower grip. As the lower grip of the tensile testing machine receded, it applied stress on the joint and subsequently its rupture.

The test samples were prepared according to composition variant S1, i.e. analogically for a roof without thermal insulation with the waterproofing membrane mechanically fastened to OSB board of $22 \mathrm{~mm}$ thickness. The fastening element to the hard base was a screw with a metal oval washer. The edge of the pressure washer of the fastening element was located $10 \mathrm{~mm}$ from the edge of the lower bitumen sheet. The use of the oval pressure washer was intentional because it provides better pressure on the lower sheet thanks to its larger surface area. As a result, the rupture of the test samples depended on the parameters of the bitumen sheet rather than on the failure of the fastening element.

Three bitumen sheet variants were chosen as the waterproofing membranes:

1. Test sample $\mathbf{F}$ - SBS modified bitumen sheet $5.2 \mathrm{~mm}$ thick, carrier: PES $180 \mathrm{~g} / \mathrm{m}^{2}$, reinforced on both sides with glass fibres, flexibility at low temperatures: $-25{ }^{\circ} \mathrm{C}$, joint length $100 \mathrm{~mm}$;

2. Test sample G - SBS modified bitumen sheet $5.2 \mathrm{~mm}$ thick, carrier: PES $180 \mathrm{~g} / \mathrm{m}^{2}$, reinforced on both sides with glass fibres, flexibility at low temperatures: $-25{ }^{\circ} \mathrm{C}$, joint length $120 \mathrm{~mm}$;

3. Test sample A - SBS modified bitumen sheet $5.0 \mathrm{~mm}$ thick, carrier: PES $180 \mathrm{~g} / \mathrm{m}^{2}$, reinforced longitudinally with glass fibres, flexibility at low temperatures: $-20{ }^{\circ} \mathrm{C}$, joint length $100 \mathrm{~mm}$;

4. Test sample D - SBS modified bitumen sheet $5.2 \mathrm{~mm}$ thick, carrier: PES $180 \mathrm{~g} / \mathrm{m}^{2}$ reinforced on both sides with glass fibres, flexibility at low temperatures: $-25^{\circ} \mathrm{C}$, joint length $120 \mathrm{~mm}$. 


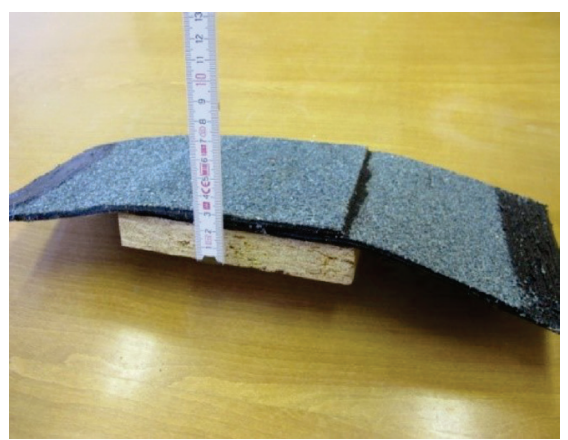

Fig. 1. Testing sample - composition variant S1 [1].

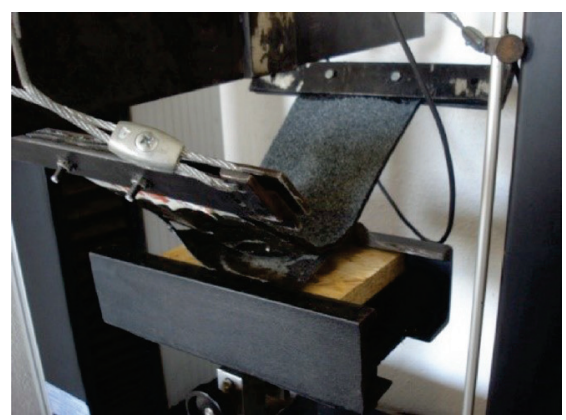

Fig. 2. Testing sample in tensile testing machine during test [1].

\section{Evaluation}

Approximately 10 samples were used for each testing sample. The resulting force is in the form $\bar{x} \pm \bar{\vartheta}(\bar{x})$, where $\bar{x}$ is the arithmetic average and $\bar{\vartheta}(\bar{x})$ is the probable measurement error. The latter was determined on the basis of the error theory for deviations of arithmetic average using the formula:

$$
\bar{\vartheta}(\bar{x})=\frac{2}{3} \sqrt{\frac{1}{n(n-1)} \sum_{i-1}^{n}\left(x_{i}-\bar{x}\right)^{2}}
$$

\section{Results of experimental measurement and discussion}

Comparing the measurement results of samples $F$ and G (Fig. 5), there is just a small difference in reached strengths of mechanically fastened joints. Sample F with joint length of $100 \mathrm{~mm}$ only showed 5\% lower values than sample G (joint $120 \mathrm{~mm}$ ).

This difference would probably be higher (Fig. 6) for bitumen sheets with lower degree of modification (flexibility at low temperatures $-20^{\circ} \mathrm{C}$ ). This comparison is not fully representative, since the parameters of samples $\mathrm{A}$ and $\mathrm{D}$ differed by carrier type and total sheet width. Nevertheless, the strength of testing sample A (joint $100 \mathrm{~mm}$ ) was approx. $22 \%$ lower than the strength of testing sample D (joint $120 \mathrm{~mm}$ ).

Detailed results and the comparison of results of all samples are shown in Table 1. 


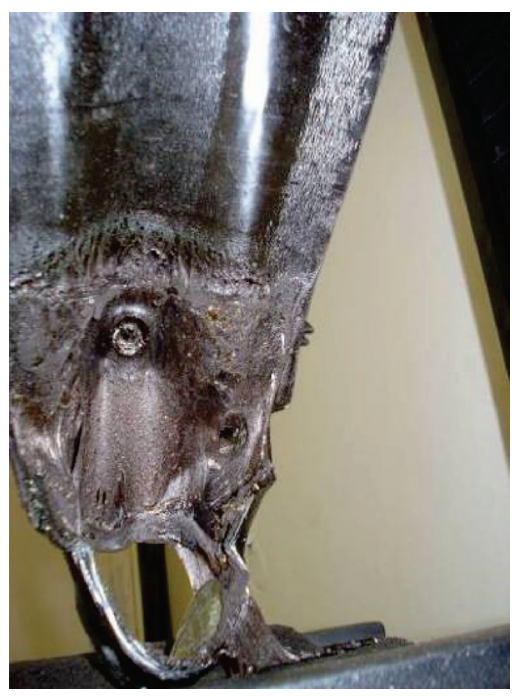

Fig. 3. Unsealed joint near a fastening element and beginning of its deformation - sample G [1].

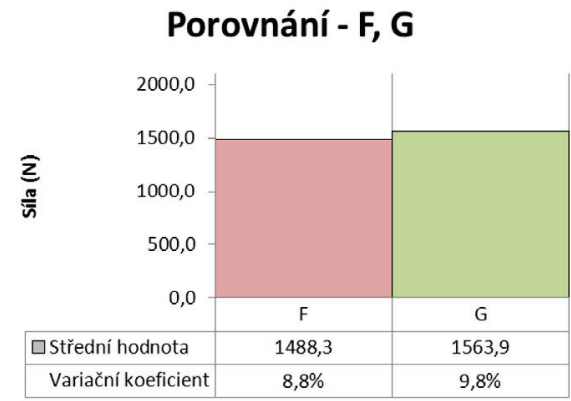

Fig. 5. Comparison of samples $F$ and $G$ (SBS modified bitumen, $-25^{\circ} \mathrm{C}$ ) [1].

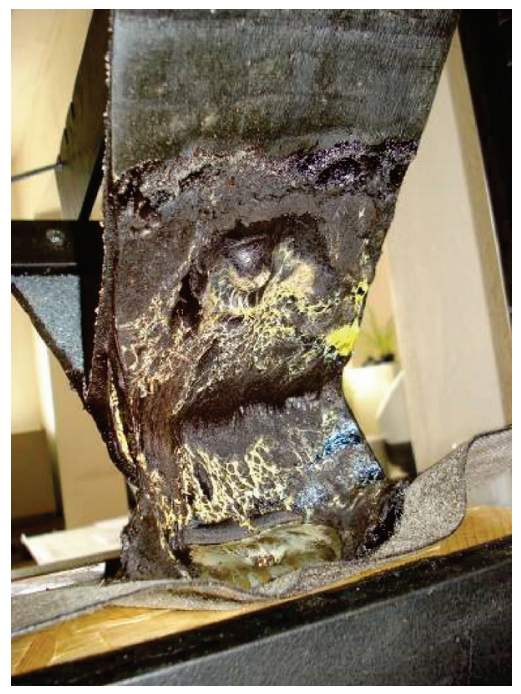

Fig. 4. Distinct unsealing of joint of testing sample A [1].

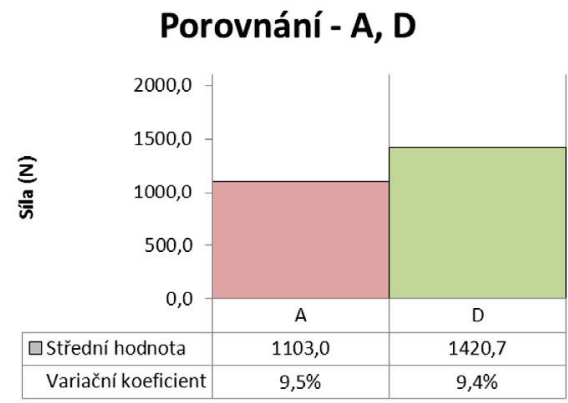

Fig. 6. Comparison of samples A and D (SBS modified bitumen, $-20^{\circ} \mathrm{C}$ ) [1].

Table 1. Comparison of testing samples.

\begin{tabular}{|c|c|c|c|c|}
\hline Test sample: & $\mathbf{F}$ & $\mathbf{G}$ & $\mathbf{A}$ & D \\
\hline $\begin{array}{l}\text { Bitumen } \\
\text { substance: }\end{array}$ & \multicolumn{4}{|c|}{ SBS modified } \\
\hline $\begin{array}{l}\text { Flexibility at low } \\
\text { temperatures: }\end{array}$ & \multicolumn{2}{|c|}{$-25^{\circ} \mathrm{C}$} & \multicolumn{2}{|c|}{$-20^{\circ} \mathrm{C}$} \\
\hline Sheet thickness: & \multicolumn{2}{|c|}{$5.2 \mathrm{~mm}$} & $5.0 \mathrm{~mm}$ & $5.2 \mathrm{~mm}$ \\
\hline Carrier: & \multicolumn{2}{|c|}{$\begin{array}{l}\text { PES reinforced on both sides, } \\
\qquad 180 \mathrm{~g} / \mathrm{m}^{2}\end{array}$} & $\begin{array}{l}\text { PES reinforced } \\
\text { longitudinally, } \\
180 \mathrm{~g} / \mathrm{m}^{2}\end{array}$ & $\begin{array}{l}\text { PES reinforced } \\
\text { on both sides, } \\
180 \mathrm{~g} / \mathrm{m}^{2}\end{array}$ \\
\hline Overlap width: & $100 \mathrm{~mm}$ & $120 \mathrm{~mm}$ & $100 \mathrm{~mm}$ & $120 \mathrm{~mm}$ \\
\hline $\begin{array}{l}\text { The highest } \\
\text { tensile strength: }\end{array}$ & \multicolumn{2}{|c|}{$\begin{array}{l}\text { longitudinally: } 900( \pm 200) \\
\mathrm{N} / 50 \mathrm{~mm} \text {, transversally: } 650( \pm \\
150) \mathrm{N} / 50 \mathrm{~mm}\end{array}$} & \multicolumn{2}{|c|}{$\begin{array}{l}\text { longitudinally: } 900( \pm 200) \mathrm{N} / 50 \mathrm{~mm} \text {, } \\
\text { transversally: } 700( \pm 150) \mathrm{N} / 50 \mathrm{~mm}\end{array}$} \\
\hline Ductility: & \multicolumn{2}{|c|}{$\begin{array}{l}\text { longitudinally and transversally: } \\
\qquad 45( \pm 10) \%\end{array}$} & $\begin{array}{l}\text { longitudinally } \\
\text { and transversally: }\end{array}$ & $\begin{array}{l}\text { longitudinally } \\
\text { and }\end{array}$ \\
\hline
\end{tabular}




\begin{tabular}{|c|c|c|c|c|}
\hline \multicolumn{2}{|c|}{} & \multicolumn{2}{|c|}{$50( \pm 10) \%$} & $\begin{array}{c}\text { transversally: } 45 \\
( \pm 10) \%\end{array}$ \\
\hline Mean value: & $\mathbf{1 4 8 8 . 3} \mathbf{~ N}$ & $\mathbf{1 5 6 3 . 9} \mathbf{N}$ & $\mathbf{1 1 0 3 . 0} \mathbf{N}$ & $\mathbf{1 4 2 0 . 7} \mathbf{~ N}$ \\
\hline $\begin{array}{c}\text { Standard } \\
\text { deviation: }\end{array}$ & $131.6 \mathrm{~N}$ & $153.2 \mathrm{~N}$ & $104.8 \mathrm{~N}$ & $134.0 \mathrm{~N}$ \\
\hline $\begin{array}{c}\text { Variation } \\
\text { coefficient: }\end{array}$ & $8.8 \%$ & $9.8 \%$ & $9.5 \%$ & $9.4 \%$ \\
\hline
\end{tabular}

\section{Conclusion}

Based on the experiment results, it can be assumed that the length of bitumen sheets with higher degree of modification has no significant effect on the resulting strength of a mechanically fastened joint. Regarding sheets with lower degree of modification, it is assumed that the resulting strength depends on the length much more.

This paper has been worked out under the project No. LO1408 "AdMaS UP - Advanced Materials, Structures and Technologies", supported by Ministry of Education, Youth and Sports under the „National Sustainability Programme I”.

This work has been financially supported by a research projects FAST-S-17-4765 from the Internal Grant Agency, Brno University of Technology, Czech Republic.

\section{References}

1. T. Petř́iček, Adhesion of joints of mechanically fastened bitumen sheets (Doctoral thesis, University of Technology, Faculty of Civil Engineering, Brno, 2013)

2. ČSN EN 13707+A2 Waterproofing sheets and foils - Reinforced roof waterproofing bitumen sheets - Definitions and characteristics (The Institute of Technical Standardization, Metrology and State Testing, Prague, 12/2009)

3. J. Plachý. MATEC Web of Conf. 93, 02004 (2017)

4. J. Plachý. MATEC Web of Conf. 93, 02006 (2017)

5. R. Smolka, J. Sobotka, J. Šulistová, MATEC Web of Conf. 93, 01009 (2017)

6. J. Sobotka, R. Smolka, MATEC Web of Conf. 93, 01008 (2017)

7. P. Kacálek, T. Petř́iček, MATEC Web of Conf. 93, 03006 (2017)

8. ETAG 006. European Technical Approval Guideline - Systems of Mechanically Fastened Flexible Roof Waterproofing Membranes. Brussels: European Organisation for Technical Assessment - EOTA, 03/2000. 
